\title{
JULIÁN Y EL MAR
}

Mariana Bernárdez*

\section{Se desliza la palabra por el agua de} la página, muestra en su juntura la identidad del mundo, ríe en su pronunciación que vuela de un labio al otro: de un ojo que mira sin saberse mirado, como si en el deletrear de las sílabas se afirmara un vínculo inmemorial, o como si el recordar fuera la posibilidad que rompe la cadencia lineal de un tiempo cuya evanescencia confirma la sospecha del absurdo. Pero sólo soy esta memoria rota y estas imágenes que a veces se trasvasan en un escrito, y escribir constata que no todo es invento, que hubo alguna vez un encuentro, que el hecho ocurrió sin ser cuestionado en su acontecer. Digo todo esto para contar que a Julián lo conocí como consecuencia de una serie de cruces y entrecruces, porque la vida es así en su simpleza.

El punto de referencia mutuo era un libro en busca de editor. Julián me leyó... y luego el mensaje fue que lo contactara a través de correo. Estaba en París y era otoño. En México llovía. El inicio de la amistad estuvo a la altura de la postmodernidad, fue totalmente virtual, aunque contenía resabios propios del género epistolar. Desde el principio me sorprendió su vocación de maestro, no sé si supe desempeñar de forma certera el papel contrario, pero en el eje de esta conversación breve y puntual, logró que volviera a repasar línea por línea todo el texto, supo

* Poeta y ensayista. 
mirar ahí donde trastabillaba: la puntuación. Confieso que esto que ahora anoto se detiene en el reparo de cada coma y cada punto.

Pocos meses después de haberle mandado el original, y creyendo haber arribado a puerto seguro, Julián con su cálculo certero tuvo a bien indicarme que el libro para ser aceptado debía incluir uno o dos ensayos más, “¡Demonios!”, pensé, y él cayó en cuenta del pasmo creativo, "Escribe algo, no sé, hasta las piedras hablan..." El resultado fue "Piedra sobre piedra", un texto cuya imagen central explora su aspecto fundacional. Para ese entonces París había quedado atrás y México era el escenario que enmarcaba la realidad virtual de este intercambio. Debo decirlo, había adquirido el hábito de cruzar correos de vez en vez. En cada misiva confirmaba su enorme erudición y su sentido del humor. La risa es, sin duda, un obsequio preciado.

Reunirnos a comer con los amigos ocurrió de forma espontánea y natural. Conservo un gratísimo recuerdo del momento, porque encontré en Julián, además de todo, a un gran conversador. En ambas ocasiones el cielo ostentaba un azul poco común y anunciaba la lluvia temprana de la tarde, pero ni la lluvia ni el frío cortaron la charla; nos sorprendía con la agudeza de sus comentarios y la memoria prodigiosa de un historiar que iba más allá del aula y de un fabular vano.

Hace un par de meses el libro fue publicado; al tenerlo entre las manos pensaba que otro hubiera sido su periplo si Julián no me hubiera acompañado en su tránsito. El "hubiera" es el tiempo de la imposibilidad, de la "in-existencia", pero incluso el sólo mentarlo es señal de que a veces el reverso y el anverso confunden su polaridad para que el hecho ocurra. Si considero este rango de probabilidad tendría que aceptar que el azar sobrepasa el límite de un juego de dados. No importa, falta poco para que comience el otoño, y continúo escribiéndole a Julián. Por cierto, hoy le he mandado una fotografía donde aparece el mar en calma. 